Mapping the stray domestic cat (Felis catus) population in New Zealand: Species distribution modelling with a climate change scenario and implications for protected areas

Aguilar, GD

http://hdl.handle.net/10026.1/4920

10.1016/j.apgeog.2015.06.019

Applied Geography

All content in PEARL is protected by copyright law. Author manuscripts are made available in accordance with publisher policies. Please cite only the published version using the details provided on the item record or document. In the absence of an open licence (e.g. Creative Commons), permissions for further reuse of content should be sought from the publisher or author. 


\title{
Mapping the stray domestic cat (Felis catus) population in New Zealand: Species distribution modelling with a climate change scenario and implications for protected areas
}

\author{
G.D. Aguilar ${ }^{\mathrm{a}, *}$, M.J. Farnworth ${ }^{\mathrm{a}, \mathrm{b}}$, L. Winder ${ }^{\mathrm{a}}$ \\ a Department of Natural Sciences, Unitec Institute of Technology, Carrington Road, Auckland 1026, New Zealand \\ b School of Biological Sciences, Plymouth University, Devon, United Kingdom
}

\section{A R T I C L E I N F O}

\section{Article history:}

Received 21 January 2015

Received in revised form

6 May 2015

Accepted 29 June 2015

Available online $\mathrm{xxx}$

\section{Keywords:}

Stray cats

Cat colonies

Species distribution modelling

Maxent

Climate change

New Zealand

Felis catus

\begin{abstract}
A B S T R A C T
Species distribution models of stray cats were developed using two types of occurrence data: (i) a combined dataset of stray cats and cat colonies in Auckland and projected to the wider New Zealand area; and (ii) population density as an analogue for country-wide stray cat occurrence. These occurrence data, together with sets of environmental variables were used as input to the Maxent modelling tool to produce maps of suitability for the species. Environmental variables used in the models consist of current bioclimatic conditions, and a future climate scenario (RCP8.5 for year 2070 CCSM model). Commonly occurring bias in the modelling process due to latitude, the area for selecting background points in model evaluation, inherent spatial autocorrelation of occurrence points, and correlated bioclimatic variables were explicitly addressed. Results show that the North Island consistently provide more suitable areas for stray cats with increased suitability in a high emission climate change condition. Key protected areas at risk from the increased suitability to stray cats are also presented.
\end{abstract}

() 2015 Elsevier Ltd. All rights reserved.

\section{Introduction}

The cat (Felis catus) has been identified as one of the world's most invasive species (Duffy \& Capece, 2012; Lowe, Browne, Boudjelas, \& De Poorter, 2000). Yet it is also the most common companion animal in many countries including New Zealand (Argante, 2008; MacKay and NZCAC, 2011) and as a consequence populations of cats (either as pets or un-owned) are in general associated spatially with human populations (Ferreira, Leitão, Santos-Reis, \& Revilla, 2011). The population densities of urban free-living, un-owned cats (also known as 'stray cats'; see Farnworth, Campbell, \& Adams, 2010) have been demonstrated to be closely linked to human population density (Aguilar \& Farnworth, 2012; 2013). The management of populations of unowned individuals, including cat colonies (Sparkes et al., 2013) that typically loosely aggregate around ad hoc provision of food and shelter is considered to be challenging. Reasons for this challenge

\footnotetext{
* Corresponding author.

E-mail addresses: gaguilar@unitec.ac.nz (G.D. Aguilar), mark.farnworth@ plymouth.ac.uk (M.J. Farnworth), lwinder@unitec.ac.nz (L. Winder).
}

include the emotional connection evident in those who care for unowned animals, perception as a public nuisance (Ash, Adams, Ash, \& Adams, 2003), predation of native fauna (Baker, Bentley, Ansell, \& Harris, 2005; Dickman, Denny, \& Buckmaster, 2010; Gillies \& Clout, 2003; Van Heezik, Smyth, Adams, \& Gordon, 2010; Woods, McDonald, \& Harris, 2003), and potential for acting as vectors of pathogens and diseases (Levinthal, 2010; Simking, Wongnakphet, Stich, \& Jittapalapong, 2010).

Decisions regarding the management of un-owned cat populations must therefore take into account a wide range of perspectives (Jarvis, 1990) that span animal (and human) welfare considerations, as well as environmental issues that focus on ecology and the conservation of biodiversity (Loss, Will, \& Marra, 2013; Marston \& Bennett, 2009; Van Heezik et al., 2010). The multifaceted human-cat relationship which is dominated by emotional attachments to domestic cats or their perceived prey are therefore considered when management strategies are developed (Clarke \& Pacin, 2002). An essential step towards developing effective management strategies is to understand the spatial and temporal distributions of cats: Thomas, Fellowes, and Baker (2012), for example, demonstrated that predation of native birds by urban domestic cats was mediated by both spatial and temporal 
processes.

Management strategies such as 'Trap-Neuter-Return' (TNR), 'capture and rehoming' and euthanasia seek to address the growth of stray cat populations in a humane way (Farnworth, Campbell, \& Adams, 2011, 2013). Despite these measures, there is no clear evidence that the management of urban cat populations has been effective. In Melbourne, Australia Marston and Bennett (2009) have shown that the main driver for the growth of the urban cat population is through reproduction of un-sterilised and un-owned cats. Within New Zealand, studies show that the sterilisation rate of owned cats is approximately 90\% (Farnworth et al., 2010; McKay, Farnworth, \& Waran, 2009), yet un-owned cat populations are seemingly growing (Aguilar \& Farnworth, 2012).

A growing un-owned cat population is of concern, particularly with respect to their impact on native fauna (Calver, Grayson, Lilith, \& Dickman, 2011; Fitzgerald, 1990). For example, un-owned cats that live in a wild state distant from human populations (Schmidt, Lopez, \& Collier, 2007) are considered to be responsible for at least $14 \%$ of extinctions of birds, mammals and reptiles globally in island environments (Medina et al., 2011). Additionally, urban un-owned cat populations may act as a source of animals that turn feral and colonise adjacent rural or semi-urban areas that may be of high conservation value (Ferreira et al., 2011) and protected in law (Van Heezik et al., 2010). Pet cats tend to have a limited home range and reduced likelihood of dispersal as their territory is centred around food and shelter provided by the owner (Kays and DeWan, 2004), whilst un-owned cats often experience significant pressure to disperse (Liberg, Sandell, Pontier, \& Natoli, 2000) primarily due to food availability. In spatial terms, urban environments may therefore act as a source (i.e. centres of dispersal) for cat dispersal.

Spatial and temporal distribution of cat populations are amenable to investigation using GIS and species distribution mapping techniques. Such analyses can: (i) evaluate and assess current un-owned cat distributions; (ii) identify natural areas that are proximal to urban areas to evaluate colonisation risk; and (iii) build future scenarios using climate models. Species distribution modelling generates maps showing the suitability of areas for a particular species and is a widely used approach, with a rapidly growing volume of work utilising improved algorithms and software tools. Scenarios can be modelled for species of interest over a range of geographic and temporal scales, using a variety of environmental, socio-economic and non-biological information layers (Booth, Nix, Busby, \& Hutchinson, 2014; Guisan et al., 2013; Sherrouse, Semmens, \& Clement, 2014). Models describing the range or distribution of species from future climate scenarios contribute to the growing work on the effects of climate change, and provide information that can be used in preparing strategic or regional management plans (Bertelsmeier, Luque, \& Courchamp, 2013; Hellman et al., 2008). The need to provide attention on the relationship between climate change, biodiversity and important species is well-documented (Bellard, Bertelsmeier, Leadley, Thuiller, \& Courchamp, 2012; De Souza, Lorini, Alves, Cordeiro, \& Vale, 2011; Irlich et al., 2014; Thomas, Franco, \& Hill, 2006; Yates et al., 2009). Specifically, observations by Huyser, Ryan, and
Cooper (2000) on changes in the use of habitats and population of an endemic bird, the lesser sheathbills (Chionis minor) of the subAntartic Marion Island brought about by the interactions of feral cats, mice and observed warming over the 20 year comparison period of the study suggests the need for further investigations on implications of climate change.

In this study, we used species distribution modelling to describe the current distribution of un-owned cats, and investigated the potential impacts of climate change on future distributions.

\section{Methodology}

ArcGIS and Maxent v3.3.3k (Phillips, Anderson, \& Schapire, 2006) were used for processing un-owned cat data available from previous studies (Aguilar \& Farnworth, 2012, 2013). Maxent has been used to model and predict the distribution of invasive species (De Queiroz et al., 2013; Domíguez-Vega, Monroy-Vilchis, BalderasValdivia, Gienger, \& Ariano-Sánchez, 2012; Elith et al., 2006), endangered and threatened flora and fauna (Shochat et al., 2010), organisms of economic significance (Blanchard, O'Farrell, \& Richardson, 2014) and ancient species (Connolly, Manning, Colledge, Dobney, \& Shennan, 2012). Based on the maximum entropy algorithm that tries to determine the probability distribution that is the most spread out or close to uniform based on constraints dictated by available data, Maxent models the distribution of a species over a defined area using the location of each sample and a set of environmental variables of the area (Phillips et al., 2006). The result is a 'suitability map' depicting the probability of occurrence of the species at each raster cell of the area covered.

Maxent is widely used (Fourcade, Engler, Rödder, \& Secondi, 2014) and found to provide better performance when compared to other approaches (Elith et al., 2006). Techniques addressing model validity and robustness such as spatial autocorrelation, background data bias, environmental heterogeneity and latitudinal bias were also utilised during data processing (Brown, 2014; Elith et al., 2011; Phillips \& Dudik, 2008).

We used un-owned cat data (stray and colony) sourced from animal welfare organisations and reported in previous papers (Aguilar \& Farnworth, 2012, 2013) as the basis for running two models. Model A was based solely from actual data modelled in Auckland and projected to the entire country. Model B used human population data as an analogue for un-owned cat presence data.

Model A (Auckland un-owned cat data) was run with the highest resolution (30 arc-second) Bioclim environmental layers downloaded from the Worldclim database (Hijmans, Cameron, Parra, Jones, \& Jarvis, 2005). Bioclim is a dataset consisting of 19 climatic variables, eleven of which are measures of temperature and eight of precipitation. The variables represent annual trends, seasonality and environmental parameters that limit or describe extreme climatic conditions. These sets of variables are considered to be more informative for modelling than simple measures such as monthly temperature and precipitation averages. Bioclim is used widely for species distribution modelling (Guisan \& Thuiller, 2005; Wakie, Evangelista, Jarnevich, \& Laituri.M, 2014; Wasowicz,

Table 1

Land cover classification from based on distances from Land Cover Database of New Zealand grouped into favourable environments for un-owned cats.

\begin{tabular}{|c|c|}
\hline Land class name & Group \\
\hline Urban Parkland/Open Space, Transport Infrastructure Built-up Area (settlement). & 5 \\
\hline Orchard, Vineyard or Other Perennial Crop Indigenous Forest, High Producing Exotic Grassland. & 4 \\
\hline Tall Tussock Grassland, Manuka and/or Kanuka, Low Producing grassland, Exotic Forest, Deciduous Hardwoods, Broadleaved Indigenous Hardwoods. & 3 \\
\hline Short-rotation Cropland, Mixed Exotic Shrubland, Gorse and/or Broom, Forest - Harvested, Flaxland, Fernland, Depleted Grassland & 2 \\
\hline $\begin{array}{l}\text { Surface Mine or Dump, Sub Alpine Shrubland, Sand or Gravel River, Permanent Snow and Ice Matagouri or Grey Scrub, Mangrove, Landslide, } \\
\text { Lake or Pond, Herbaceous Saline, Vegetation, Herbaceous Freshwater Vegetation, Gravel or Rock, Estuarine Open Water, Alpine Grass/Herbfield }\end{array}$ & 1 \\
\hline
\end{tabular}


Table 2

Distances reported as home ranges in previous studies.

\begin{tabular}{|c|c|c|c|c|}
\hline \multicolumn{2}{|c|}{ Reported home range (Ha) } & \multirow{2}{*}{$\begin{array}{l}\text { Rarefy distance } \\
2.99\end{array}$} & \multirow{2}{*}{$\begin{array}{l}\text { Location } \\
\text { Perth, Australia }\end{array}$} & \multirow{2}{*}{$\frac{\text { Reference }}{\text { Lilith (2007) }}$} \\
\hline Stray cats & $0.07-2.86$ & & & \\
\hline & $2.70-7.9$ & 4.98 & Canberra, Australia & Barrat (1997) \\
\hline & $0.1-10.1$ & 5.63 & Christchurch & Morgan (2002) \\
\hline & $0.5-21.8$ & 8.27 & Dunedin, NZ & Van Heezik et al. (2010) \\
\hline \multirow[t]{3}{*}{ Feral cats } & $80-990$ & 55.77 & NW Victoria, Australia & Jones \& Coman (1982) \\
\hline & $42-840$ & 51.37 & Mackenzie Basin, South Island, New Zealand & Norbury et al. (1998) \\
\hline & $178-2486$ & 56.26 & Central South Island, New Zealand & Recio et al. (2010) \\
\hline
\end{tabular}

Table 3

AUC values for the spatially rarefied data from the initial Maxent run (highest values are in bold).

\begin{tabular}{llllr}
\hline & Raster value & AUC training & AUC test & No of pts \\
\hline Model A & Group 1 & - & 0.5 & 1 \\
& Group 2 & 0.906 & 0.811 & 3 \\
& Group 3 & 0.829 & 0.901 & 11 \\
& Group 4 & 0.838 & 0.605 & 38 \\
& Group 5 & $\mathbf{0 . 9 0 6}$ & $\mathbf{0 . 8 2 7}$ & 78 \\
& All Points & 0.836 & 0.737 & 131 \\
& Original Points from Stray Cat Data & & 2953 \\
Model B & Group 1 & 0.697 & 0.602 & 56 \\
& Group 2 & 0.804 & 0.781 & 713 \\
& Group 3 & 0.729 & 0.724 & 4663 \\
& Group 4 & 0.853 & 0.655 & 80 \\
& Group 5 & $\mathbf{0 . 9 1 9}$ & $\mathbf{0 . 9 0 0}$ & $\mathbf{3 7 6}$ \\
& All Points & 0.697 & 0.691 & 5888 \\
& Original Points from NZ Population Data & 41,127 \\
\hline
\end{tabular}

Pasierbinski, Przedpelska-Wasowicz, \& Kristinsson, 2014). Maxent was used to develop a model using the Auckland data and was then projected into the entire New Zealand land mass. The same Bioclim environmental layers were used set at the country-wide scale, and similarly projected into the future climate scenario (RCP8.5 for year 2070 CCSM model). This approach was similar to those used when projecting locally occurring species data to a global or wider regional scales to model the spread of invasive species (Ficetola, Thuiller, \& Miaud, 2007; Thuiller et al., 2005), identify suitable areas for translocations (Fouquet, Ficetola, Haigh, \& Gemmell, 2010) and investigate areas previously unexplored (Raxworthy et al. 2003).

Model B used Auckland-based un-owned cat and human population densities to determine the minimum non-zero value for unowned cat density in order to determine the cut-off value of population density to select official census areas (called mesh blocks) serving as the basis for occurrence points. This was premised on the

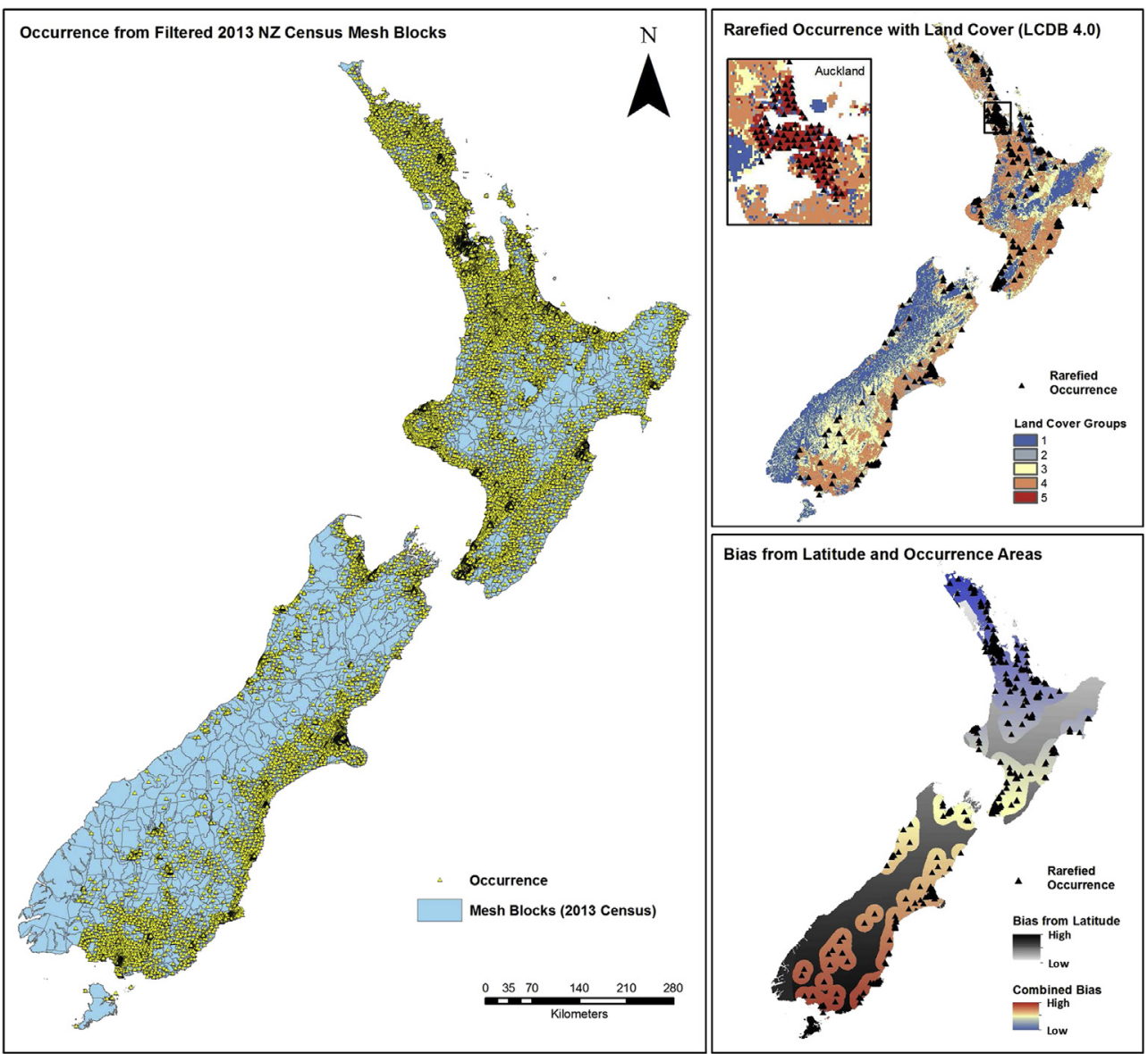

Fig. 1. Occurrence data derived from NZ mesh blocks (left) with rarefied Group 5 based occurrence points (top right) and bias file rasters (bottom right). 
work of Aguilar and Farnworth (2012), where population density was identified as a major factor indicating the presence of unowned cats. The mesh blocks were converted to point features located at the centroid of each area to represent stray cat occurrence. This approach follows Aragón, Coca-Abia, Llorente, and Lobo (2013), who used centroids of municipal polygonal areas as presence points for modelling of locust species in Spain. This was also similar to approaches that generate species occurrences from data with varying spatial resolution of species presence records (Howard et al., 2012; Kumar, Graham, West, \& Evangelista, 2014).

Evident clustering of the occurrence data and the concentration of smaller mesh blocks at high population density areas hints at spatial autocorrelation. Spatial autocorrelation may result in model being unable to predict spatially independent data, leading to inflated performance measure values (Boria, Olson, Goodman, \& Anderson, 2014; Nazeri, Kumar, Jusoff, \& Bahaman, 2014; Syfert, Smith, \& Coomes, 2013; Veloz, 2009). Therefore, the Spatially Rarefy Occurrence Data in the SDMTooblox in ArcMap (Brown, 2014) was used as a filter by eliminating redundant or spatially autocorrelated occurrence points within a range of specified distances (Brown, 2014). This step also included the grouping of occurrence points based on land cover classes specified in the Landcare Research (2014) Land Cover Database of New Zealand (LCDB Version 4.0; Table 1). The analysis created groups of occurrence points which were used as input into a preliminary Maxent run. Using the common evaluation metric for predictive performance AUC (Area Under Curve; Swets, 1988), the group with the highest AUC value was selected for running the final models and projections.

The Bioclim environmental variables used in modelling were found to be highly correlated (Metzger et al., 2013), leading to difficulties in interpreting the contribution of each variable to the model. Using the SDMToolbox, highly correlated variables were identified and excluded ensuring that uncorrelated variables were used when Maxent was run.

To address errors associated with latitude and the commonly encountered overfitting problem identified in Maxent (Anderson \& Raza, 2010; Elith et al., 2011; Radosavljevic \& Anderson, 2014), bias files were created. The first bias file corrected the error associated with latitudinal accuracy of coordinate data where areas farther from the equator have greater positional error. The second bias file addressed the sampling area for collecting the background points used for model evaluation. Normally, Maxent uses the entire area for deriving background points. This results in a higher percentage of commission errors or false positives due to the selection of background points from localities that may be environmentally suitable but not occupied by the species. Several approaches to limit the area ranged from simple radial distances from known occurrences to minimum convex polygons from occurrences to more elaborate combinations of area definitions (Barbet-Massin, Jiguet, Albert, \& Thuiller, 2012; Brown, 2014; Phillips et al., 2009). We selected the convex hull radial area connected with radial buffers from the occurrences. The radial buffer distance was based on home ranges collated from previous un-owned cat studies and calculated as the distance between the centres of circles that have areas equal to the maximum home range (Table 2). Compared to mainly urban un-owned cats, feral cats in rural areas are considered to have greater home ranges, with a minimum of 42 ha (Norbury, Norbury, \& Heyward, 1998) and a maximum of 2486 ha (Recio, Mathieu, Maloney, \& Seddon, 2010). This translated to a range from 2.99 to $56.2 \mathrm{~km}$ using the radius of the home range area as the end-to-end distance that the feral cat potentially travels. While
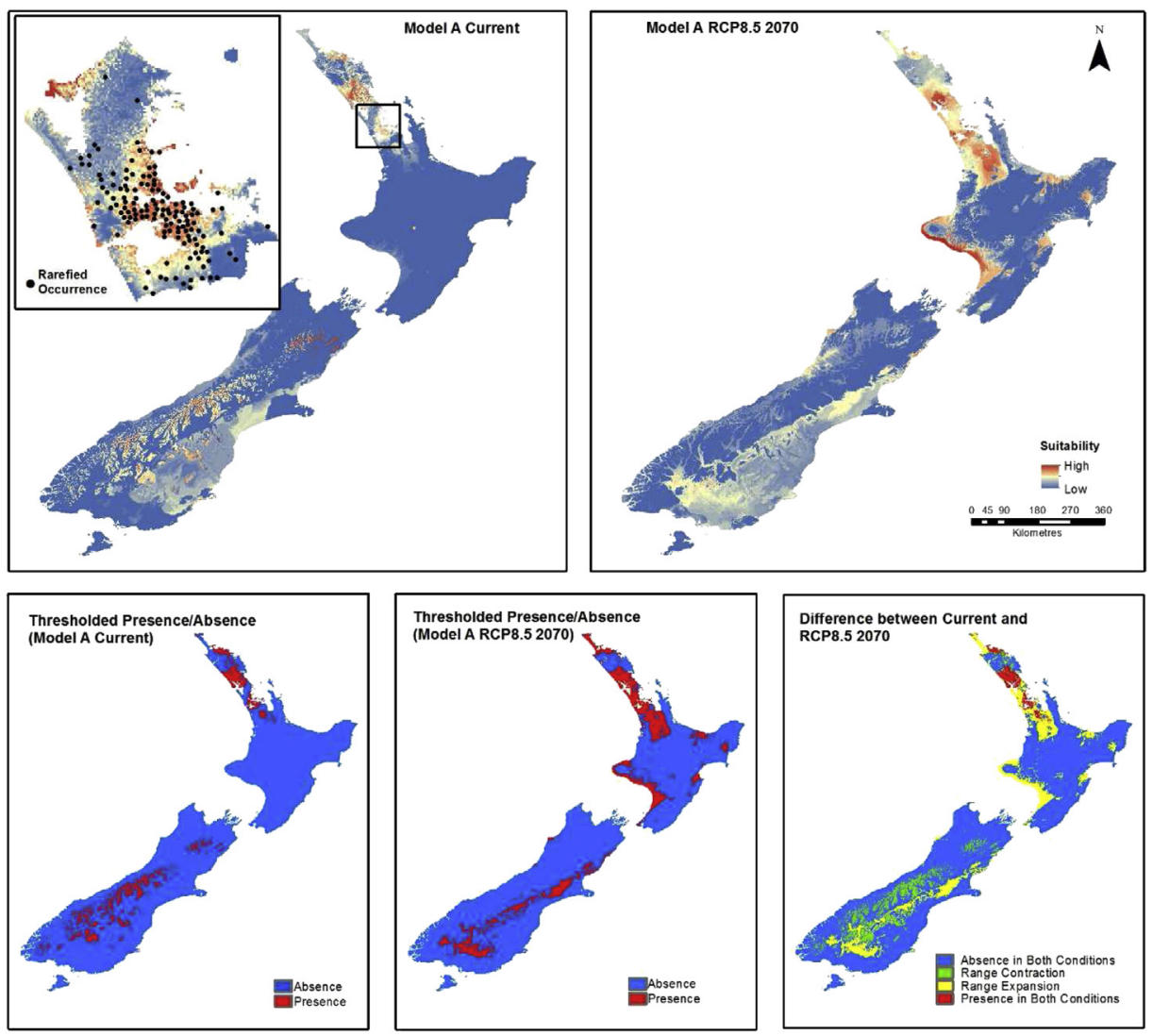

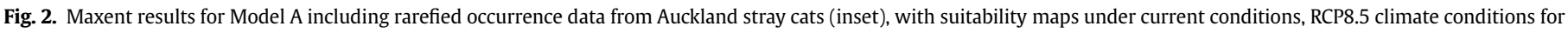
2070 (top maps), thresholded presence for both conditions and range contraction/expansion (bottom maps). 

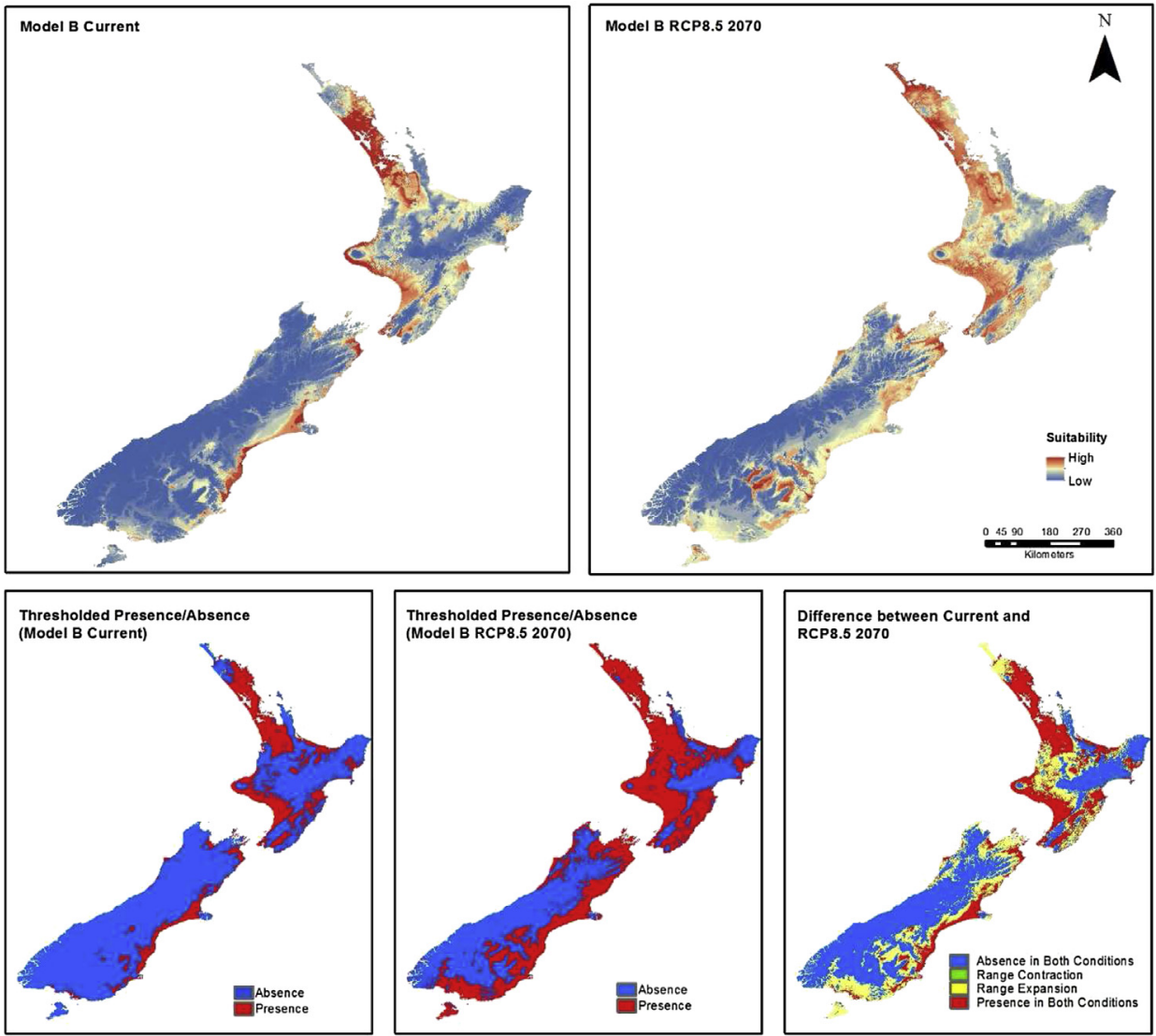

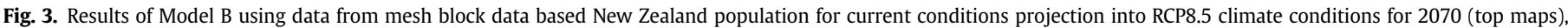
thresholded presence for both conditions and range contractions/expansions (bottom maps).

rural feral home ranges were a magnitude greater than urban stray cats' home range, we used these maximum estimates to set the background area to account for the potential for un-owned cats to become feral (Brown, 2014).

The availability of the latest scenarios for different future bioclimatic conditions based on the 5th IPCC report made the modelling of future suitability of stray cats possible (IPCC 2013; Carraro, Lanza, \& Tavoni, 2014). Using the worst case scenario of RCP8.5, Bioclim layers for 2070 (NCAR, 2012) was included as a projection to enable the comparison between current and future suitability conditions for both Models A and B.

Resulting suitability maps were overlaid over the protected areas of New Zealand as categorised in the IUCN system. Consisting of 3954 areas over an area of 108,327 square kilometres, the categories included: Ia, Strict Nature Reserve; Ib, Wilderness Area; II, National Park; III, National Monument; IV, Habitat Species Management Area; V, Protected Landscape and Seascape. Results of clipping the suitability maps with protected areas showed which areas were most suitable based on the output of the two models for current and future conditions or scenarios. In order to compare the scenarios, raster cells of the suitability maps within the protected areas were counted based on their values and grouped into ordered classes depicting suitability (1: very low, 2: low, 3: medium, 4: high, 5: very high).

\section{Results and discussion}

Rarefication of location data for Auckland for Model A resulted in 131 points that were not spatially autocorrelated, representing $4 \%$ of the original 2953 occurrences. For Model B, the minimum population density cut-off value was 0.091 persons $\mathrm{km}^{-2}$ (i.e. the population density threshold below which un-owned cats did not occur). A total of 41,127 mesh blocks with population densities greater than the cut off value were converted into point features located at the centroid of each polygon. When the Spatially Rarefy Occurrence Data included in the SDMToolbox was run, a total of 5888 points resulted, showing that $14 \%$ were non-spatially correlated.

Results of the initial Maxent run for Models A and B using the set of rarefied occurrences showed that Group 5 had better performance compared to other groups (based on inspection of AUC values). This was expected as the land cover types associated with higher human population densities were mainly under the land cover class for Group 5. Hence, the sets of points in Group 5 were

Table 4

Number of raster cells representing presence and absence resulting from thresholding current and future suitability maps.

\begin{tabular}{|c|c|c|c|c|}
\hline & $\begin{array}{l}\text { Absent in both } \\
\text { (Non-occupancy) }\end{array}$ & $\begin{array}{l}\text { Range contraction (Presence: } \\
\text { current conditions only) }\end{array}$ & $\begin{array}{l}\text { Range expansion (Presence: } \\
\text { future conditions only) }\end{array}$ & Present in both (Occupancy) \\
\hline Model A & $78.3 \%$ & $6.3 \%$ & $13.2 \%$ & $2.3 \%$ \\
\hline Model B & $48.4 \%$ & $0.4 \%$ & $28.2 \%$ & $23.0 \%$ \\
\hline
\end{tabular}


used for both models (Table 3). The bias files included in the Maxent model resulted from combining latitudinal bias with and area coverage based on rarefied occurrence data (Fig. 1).

Results of Model A (using the Auckland stray cat data with Bioclim variables and projected into the entire New Zealand land mass with current and future climate conditions) showed changes in the suitability for stray cats (Fig. 2). Areas in the North Island were shown to have more favourable conditions compared to the South Island with increasing areas for both in the future climate scenario. This is consistent with the greater percentage of population in the North Island with more areas favourable for the species. When a 10th percentile presence logistic threshold for both current and future conditions was used, an increase in the areas predicted to be presence areas for stray cats was evident (Fig. 2).

Results of the population-based model (Model B) showed a greater area of environmental suitability of New Zealand to stray cats. Many of the population centers had greater values whilst higher altitudes, remote wilderness and the majority of the South Island were not as favourable. When the model was projected to
RCP8.5 for the year 2070, a result consistent with Model A was shown, depicting wider and more intense suitability (Fig. 3).

A simple comparison of the two models showed better AUC values reported for Model B. Therefore, better performance measures for using population density (as an analogue for un-owned cats) compared to using actual presence data (from a local region and expanding to a larger extent) was observed. Caution is warranted in this result however, and further model validation as well as testing with other occurrence data would be required to confirm this observation. Both Models A and B showed an increase in the number of presence cells at the 10th percentile presence threshold in future conditions with Model $B$ reporting presence at double the number of cells as Model A (Table 4).

The maps of suitability should be considered only within the limits of the Bioclim database environmental variables used in the models. Another consideration is the background area used for the calculating suitability. In Model A, particularly in the future scenario, occurrence points were only available in the Auckland region and limits to the background area cannot be determined when the

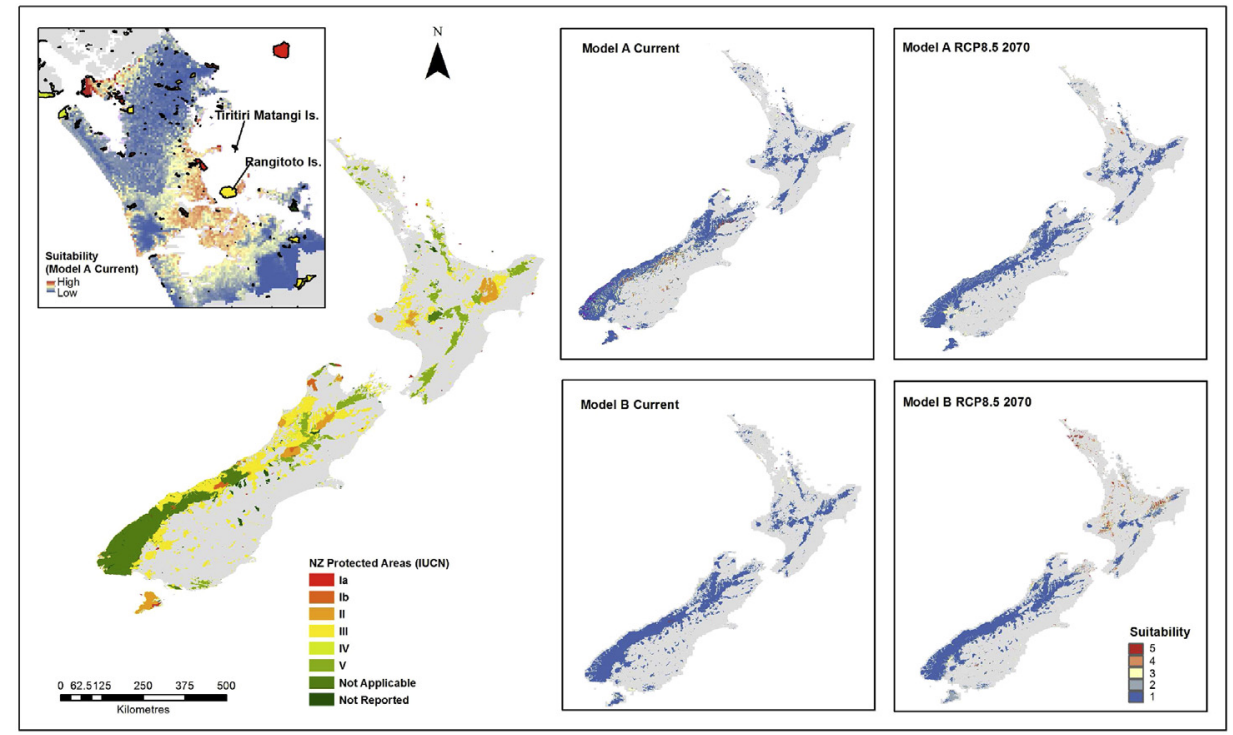

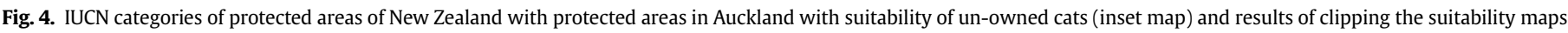
to the protected areas for Model A (right-top maps) and Model B (right-bottom maps).

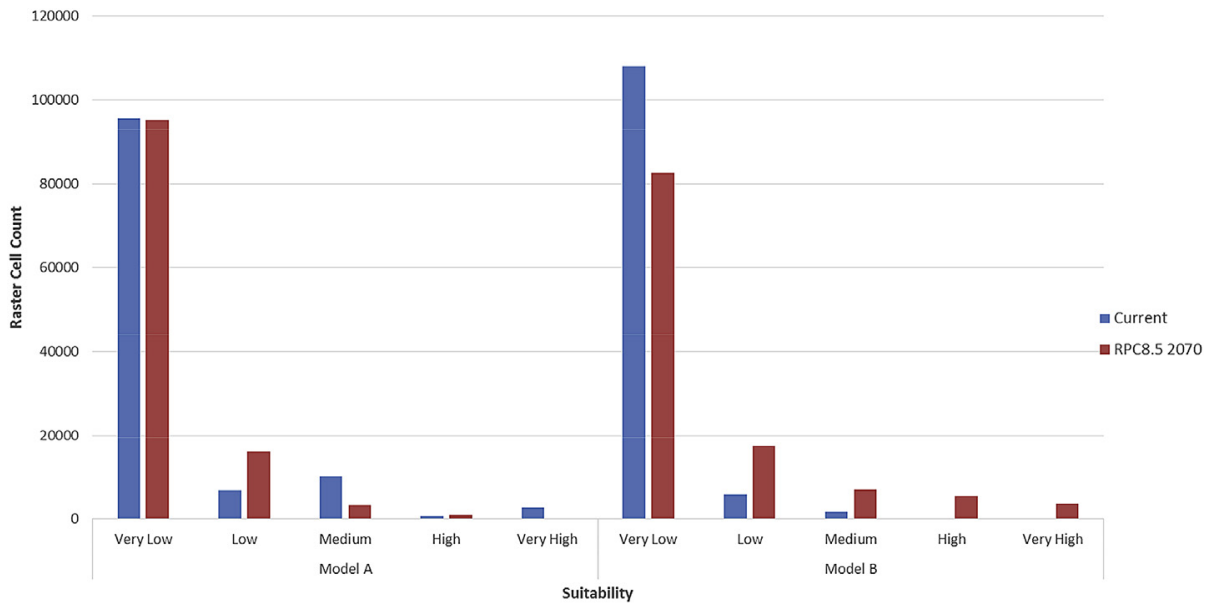

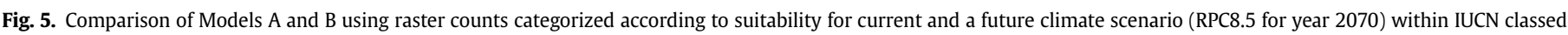
protected areas. 
model was projected to a larger scale, resulting in the entire area included in the calculation. In Model B, there may be room to improve the background area available by changing the home range values which serve as the basis for the background area calculation. For both models, it was evident that the area deemed suitable for un-owned cats is expected to increase quite substantially in a high emission scenario.

Whilst the results of the Model A projection into entire New Zealand area needs to be treated with caution, the resulting suitability map of the Auckland Region is of value to planners and managers of the region and the modelling experience may be of value to other areas where occurrence data may be available (either now or in the future).

When the suitability map of current conditions was combined with the IUCN protected sites for the Auckland region (Fig. 4), the highly suitable areas adjacent to important conservation sites demonstrate the importance of monitoring and surveillance for pest management purposes. These include protected areas such as Tiritiri Matangi and Rangitoto Islands (inset map in Fig. 5), where past and continuing pest eradication efforts include those focussed on cats, possums and other small mammals that preyed on native birds (Graham, Veitch, Aguilar, \& Galbraith, 2013).

Clipping the resulting suitability maps with existing IUCN categories of protected areas of New Zealand showed the differences between the models (Fig. 5) and the changes of suitability in current conditions and the future scenario of RCP8.5 for 2070. A major difference between the two models was the greater proportion of suitable areas found in the North Island compared to the South Island for Model B. In terms of the climate change scenario, a movement of suitable areas to the South seems to be present in Model A whilst in Model B, an increased concentration and areas that are highly suitable in the North Island is evident.

When raster cells of the suitability maps within the IUCN protected areas were classified into five groups based on the risk scores ( 1 - very low, 2 - low, 3 - medium, 4 - high and 5 - very high) and raster cell counts between current and future conditions compared, differences between the models were evident (Fig. 5). Model B predicted more highly suitable areas for the species and Model A showed an increase in the area of low suitability, but, a decrease in areas of medium suitability, no change in high suitability, and a decrease in very high suitability by raster count. This was consistent with the overall contraction and expansion data showing Model B to have a much greater range expansion prediction.

\section{Conclusion}

Species distribution modelling provided a suitable approach to visualize the spatial characteristics of stray cats in New Zealand and investigate how they may impact areas that are considered to be environmentally important. Modelling based on two data sources, one from actual occurrence data and another using population density as an analogue, provided a comparison of performance that hinted at the advantages of the latter in cases when attempting to project from a smaller region to a much wider geographical area. Projections to a climate change-based scenario showed a consistent increase in the area and intensity of areas suitable for un-owned cats. Overlaying the protected areas of the country into the suitability maps helped identify which protected areas were more suitable for un-owned in current and a future climatic condition. Further work in refining the models, gathering actual occurrence data from the entire country and the use of bioclimatic layer representing additional emission scenarios is needed to provide a more comprehensive set of maps depicting the suitability of New Zealand to stray cats. This approach could contribute to the development of un-owned cat management strategies through the establishment of NZ-wide suitability maps under both current and future conditions.

\section{References}

Aguilar, G. D., \& Farnworth, M. J. (2012). Stray cats in Auckland, New Zealand: discovering geographic information for exploratory spatial analysis. Applied Geography, 34, 230-238. http://dx.doi.org/10.1016/j.apgeog.2011.11.011.

Aguilar, G. D., \& Farnworth, M. J. (2013). Distribution characteristics of unmanaged cat colonies over a 20 year period in Auckland, New Zealand. Applied Geography, 37, 160-167. http://dx.doi.org/10.1016/j.apgeog.2012.11.009.

Anderson, R. P., \& Raza, A. (2010). The effect of the extent of the study region on GIS models of species geographic distributions and estimates of niche evolution: preliminary tests with montane rodents (genus Nephelomys) in Venezuela. Journal of Biogeography, 37, 1378-1393.

Aragón, P., Coca-Abia, M. M., Llorente, V., \& Lobo, J. M. (2013). Estimation of climatic favourable areas for locust outbreaks in Spain: integrating species' presence records and spatial information on outbreaks. Journal of Applied Entomology, 137(8), 610-623. http://dx.doi.org/10.1111/jen.12022.

Argante, J. (2008). Mad about cats. North and South, 264, 60-67.

Ash, S. J., Adams, C. E., Ash, S. J., \& Adams, C. E. (2003). Public preferences for freeranging domestic cat (Felis catus) management options. Wildlife Society Bulletin, 31(2), 334-339.

Baker, P. J., Bentley, A. J., Ansell, R. J., \& Harris, S. (2005). Impact of predation by domestic cats Felis catus in an urban area. Mammal Review, 35(3-4), 302-312.

Barbet-Massin, M., Jiguet, F., Albert, C. H., \& Thuiller, W. (2012). Selecting pseudoabsences for species distribution models: how, where and how many? Methods in Ecology and Evolution, 3, 327-338.

Barratt, D. G. (1997). Home range size, habitat utilisation and movement patterns of suburban and farm cats Felis catus. Ecography, 20(3), 271-280. http:/ dx.doi.org/10.1111/j.1600-0587.1997.tb00371.x.

Bellard, C., Bertelsmeier, C., Leadley, P., Thuiller, W., \& Courchamp, F. (2012). Impacts of climate change on the future of biodiversity. Ecology Letters. http:// dx.doi.org/10.1111/j.1461-0248.2011.01736.x.

Bertelsmeier, C., Luque, G. M., \& Courchamp, F. (2013). Increase in quantity and quality of suitable areas for invasive species as climate changes. Conservation Biology, 27(6), 1458-1467. http://dx.doi.org/10.1111/cobi.12093.

Blanchard, R., O'Farrell, P. J., \& Richardson, D. M. (2014). Anticipating potential biodiversity conflicts for future biofuel crops in South Africa: incorporating spatial filters with species distribution models. GCB Bioenergy. http://dx.doi.org/ 10.1111/gcbb.12129. n/a-n/a.

Booth, T. H., Nix, H. A., Busby, J. R., \& Hutchinson, M. F. (2014). Bioclim: the first species distribution modelling package, its early applications and relevance to most current MaxEnt studies. Diversity and Distributions, 20(1), 1-9.

Boria, R. A., Olson, L. E., Goodman, S. M., \& Anderson, R. P. (2014). Spatial filtering to reduce sampling bias can improve the performance of ecological niche models. Ecological Modelling, 275, 73-77. http://dx.doi.org/10.1016 j.ecolmodel.2013.12.012.

Brown, J. L. (2014). SDMtoolbox: a python-based GIS toolkit for landscape genetic, biogeographic and species distribution model analyses. Methods in Ecology and Evolution, 5(7), 694-700. http://dx.doi.org/10.1111/2041-210X.12200.

Calver, M. C., Grayson, J., Lilith, M., \& Dickman, C. R. (2011). Applying the precautionary principle to the issue of impacts by pet cats on urban wildlife. Biological Conservation, 144, 1895-1901.

Carraro, C., Lanza, A., \& Tavoni, M. (2014). All you need to Know about the IPCC 5th assessment report. Mitigation of Climate Change. Review of Environment, Energy and Economics-Re3.

Clarke, A. L., \& Pacin, T. (2002). Domestic cat "colonies" in natural areas: a growing exotic species threat. Natural Areas Journal, 22(2), 154-159.

Connolly, J., Manning, K., Colledge, S., Dobney, K., \& Shennan, S. (2012). Species distribution modelling of ancient cattle from early Neolithic sites in SW Asia and Europe. The Holocene, 22(9), 997-1010.

De Queiroz, D. L., Majer, J., Burckhardt, D., Zanetti, R., Fernandez, J. I. R., de Queiroz, E. C., et al. (2013). Predicting the geographical distribution of Glycaspis brimblecombei (Hemiptera: Psylloidea) in Brazil. Australian Journal of Entomology, 52(1), 20-30. http://dx.doi.org/10.1111/aen.12001.

De Souza, T. V., Lorini, M. L., Alves, M. A. S., Cordeiro, P., \& Vale, M. M. (2011) Redistribution of threatened and endemic Atlantic forest birds under climate change. Natureza a Conservacao, 9(2), 214-218. http://dx.doi.org/10.4322/ natcon.2011.028.

Dickman, C. R., Denny, E., \& Buckmaster, T. (2010). Identification of sites of high conservation priority impacted by feral cats. Report for the Australian Government Department of the Environment, Water, Heritage and the Arts. Canberra, Australia.

Domíguez-Vega, H., Monroy-Vilchis, O., Balderas-Valdivia, C. J., Gienger, C. M., \& Ariano-Sánchez, D. (2012). Predicting the potential distribution of the beaded lizard and identification of priority areas for conservation. Journal for Nature Conservation, 20(4), 247-253. http://dx.doi.org/10.1016/j.jnc.2012.04.003.

Duffy, D. C., \& Capece, P. (2012). Biology and impacts of Pacific island invasive species. 7. The domestic cat (Felis catus). Pacific Science, 66(2), 173-212.

Elith, J. H., Graham, C., P Anderson, R., Dudík, M., Ferrier, S., Guisan, A., et al. (2006) Novel methods improve prediction of species' distributions from occurrence data. Ecography, 29(2), 129-151. http://dx.doi.org/10.1111/j.2006.0906- 
7590.04596.x.

Elith, J., Phillips, S. J., Hastie, T., Dudík, M., Chee, Y. E., \& Yates, C. J. (2011). A statistica explanation of MaxEnt for ecologists. Diversity and Distributions, 17(1), 43-57. http://dx.doi.org/10.1111/j.1472-4642.2010.00725.x.

Farnworth, M. J., Adams, N. J., Seksel, K., Waran, N. K., Beausoleil, N. J., \& Stafford, K. J. (2013). Veterinary attitudes towards pre-pubertal gonadectomy of cats: a comparison of samples from New Zealand, Australia and the United Kingdom. New Zealand Veterinary Journal, 61(4), 226-233.

Farnworth, M. J. Campbell, J., \& Adams, N. J. (2010). Public awareness in New Zealand of animal welfare legislation relating to cats. New Zealand Veterinary Journal, 58, 213-217.

Farnworth, M. J., Campbell, J., \& Adams, N. J. (2011). What's in a name? Perceptions of stray and feral cat welfare and control in Aotearoa New Zealand. Journal of Applied Animal Welfare Science, 14, 59-74.

Ferreira, J. P., Leitão, I., Santos-Reis, M., \& Revilla, E. (2011). Human-related factors regulate the spatial ecology of domestic cats in sensitive areas for conservation. PloS One, 6(10), e25970.

Ficetola, G. F., Thuiller, W., \& Miaud, C. (2007). Prediction and validation of the potential global distribution of a problematic alien invasive species - the American bullfrog. Diversity and Distributions, 13(4), 476-485. http://dx.doi.org 10.1111/j.1472-4642.2007.00377.x

Fitzgerald, B. M. (1990). Is cat control needed to protect urban wildlife? Environmental Conservation, 17(2), 168-169.

Fouquet, A., Ficetola, G. F., Haigh, A., \& Gemmell, N. (2010). Using ecological niche modelling to infer past, present and future environmental suitability for Leio pelma hochstetteri, an endangered New Zealand native frog. Biological Conservation, 143(6), 1375-1384. http://dx.doi.org/10.1016/j.biocon.2010.03.012.

Fourcade, Y., Engler, J. O., Rödder, D., \& Secondi, J. (2014). Mapping species distributions with MAXENT using a geographically biased sample of presence data: a performance assessment of methods for correcting sampling bias. PloS One, 9(5), e97122. http://dx.doi.org/10.1371/journal.pone.0097122.

Gillies, C., \& Clout, M. N. (2003). The prey species of domestic cats in two suburbs of Auckland City, New Zealand. Journal of Zoology, 259, 309-315.

Graham, M., Veitch, D. Aguilar, G., \& Galbraith, M. (2013). Monitoring terrestrial bird populations on Tiritiri Matangi island, Hauraki Gulf, New Zealand, 1987 2010. New Zealand Journal of Ecology, 37(3), 359-369. Parker.

Guisan, A., \& Thuiller, W. (2005). Predicting species distribution: offering more than simple habitat models. Ecology letters, 8(9), 993-1009.

Guisan, A., Tingley, R., Baumgartner, J. B., Naujokaitis-Lewis, I., Sutcliffe, P. R. Tulloch, A. I. T., et al. (2013). Predicting species distributions for conservation decisions. Ecology Letters, 1424-1435. http://dx.doi.org/10.1111/ele.12189.

Hellmann, J. J., Byers, J. E., Bierwagen, B. G., \& Dukes, J. S. (2008). Five potential consequences of climate change for invasive species. Conservation Biology, 22, 534-543. http://dx.doi.org/10.1111/j.1523-1739.2008.00951.x.

Hijmans, R. J., Cameron, S. E., Parra, J. L., Jones, P. G., \& Jarvis, A. (2005). Very high resolution interpolated climate surfaces for global land areas. Internationa Journal of Climatology, 25(15), 1965-1978. http://dx.doi.org/10.1002/joc.1276.

Howard, A. M., Bernardes, S., Nibbelink, N., Biondi, L., Presotto, A., Fragaszy, D. M. et al. (2012). A maximum entropy model of the bearded capuchin monkey habitat incorporating topography and spectral unmixing analysis. In ISPRS annals of the photogrammetry, remote sensing and spatial information sciences, 2012 XXII ISPRS congress, 25 August - 01 September, Melbourne, Australia, (I-2) (pp. 7-11)

Huyser, O., Ryan, P. G., \& Cooper, J. (2000). Changes in population size, habitat use and breeding biology of lesser sheathbills (Chionis minor) at Marion Island: impacts of cats, mice and climate change? Biological Conservation, 92(3), 299-310. http://dx.doi.org/10.1016/S0006-3207(99)00096-8.

Irlich, U. M., Richardson, D. M., Davies, S. J. Chown, S. L., Ziska, L. H., \& Dukes, J. S. (2014). Climate change and alien species in South Africa. In L. H. Ziska, \& J. S. Dukes (Eds.), Invasive species and global climate change (vol. 4, pp. 129-147) CABI.

Jarvis, P. J. (1990). Urban cats as pests and pets. Environmental Conservation, 17(2), $169-171$

Jones, E., \& Coman, B. J. (1982). Ecology of the feral cat in S.E. Australia. III: home ranges and population ecology in semiarid N.W. Victoria. Australian Wildlife Research, 9, 409-420.

Kays, R. W., \& DeWan, A. a (2004). Ecological impact of inside/outside house cats around a suburban nature preserve. Animal Conservation, 7(3), 273-283. http: dx.doi.org/10.1017/S1367943004001489.

Kumar, S., Graham, J., West, A. M., \& Evangelista, P. H. (2014). Using district-leve occurrences in MaxEnt for predicting the invasion potential of an exotic in sect pest in India. Computers and Electronics in Agriculture, 103, 55-62. http:/ dx.doi.org/10.1016/j.compag.2014.02.007.

Landcare Research. (2014). LCDB v4.0-land cover database version 4.0. Retrieved from: https://lris.scinfo.org.nz/layer/412-lcdb-v40-land-cover-databaseversion-40/.

Levinthal, J. (2010). The community context of animal and human maltreatment: Is there a relationship between animal maltreatment and human maltreatment: Does neighbourhood context matter?. Publicly accessible Penn Dissertations. Paper 274 http://repository.upenn.edu/edissertations/274.

Liberg, O., Sandell, M., Pontier, D., \& Natoli, E. (2000). Density spatial organisation and reproductive tactics in the domestic cats and other felids. In D. C. Turner, \& P. Bateson (Eds.), The domestic cat: The biology of its behaviour UK Cambridge ( $\mathrm{pp}$. 119-147).

Lilith, M. (2007). Do pet cats (Felis catus) have an impact on species richness and abundance of native mammals in low-density Western Australian suburbia? (Doctoral dissertation, Murdoch University).

Loss, S. R., Will, T., \& Marra, P. P. (2013). The impact of free-ranging domestic cats on wildlife of the United States. Nature Communications, 4, 1396. http://dx.doi.org/ $10.1038 /$ ncomms2380.

Lowe, S., Browne, M., Boudjelas, S., \& De Poorter, M. (2000) 100 of the World's worst invasive alien species: A selection from the global invasive species database. The invasive species specialist group (ISSG), a specialist group of the species survival commission (SSC) of the world conservation union (IUCN) (p. 12).

MacKay, J., \& NZCAC (New Zealand Companion Animal Council Incorporated). (2011). Companion animals in New Zealand.

Marston, L. C., \& Bennett, P. C. (2009). Admissions of cats to animal welfare shelters in Melbourne, Australia. Journal of Applied Animal Welfare Science: JAAWS, 12(3), 189-213. http://dx.doi.org/10.1080/10888700902955948.

McKay, S. A., Farnworth, M. J., \& Waran, N. K. (2009). Current attitudes towards, and incidence of, sterilization of cats and dogs by owners in Auckland, New Zealand. Journal of Applied Animal Welfare Science, 12, 331-334.

Medina, F. M., Bonnaud, E., Vidal, E., Tershy, B. R., Zavaleta, E. S., Donlan, C. J., et al. (2011). A global review of the impacts of invasive cats on island endangered vertebrates. Global Change Biology, 17(11), 3503-3510. http://dx.doi.org/10.1111/ j.1365-2486.2011.02464.x.

Metzger, M. J., Bunce, R. G., Jongman, R. H., Sayre, R., Trabucco, A., \& Zomer, R. (2013). A high-resolution bioclimate map of the world: a unifying framework for global biodiversity research and monitoring. Global Ecology and Biogeography, 22(5), 630-638.

Morgan, S. A. (2002). Movements and hunting activity of house cats (Felis catus) living around Travis Wetland, Christchurch, New Zealand. Master's Thesis. Dunedin: University of Otago.

Nazeri, M., Kumar, L., Jusoff, K., \& Bahaman, A. R. (2014). Modelling the potential distribution of sun bear in krau wildlife reserve, Malaysia. Ecological Informatics, 20, 27-32. http://dx.doi.org/10.1016/j.ecoinf.2014.01.006.

NCAR GIS Program. (2012). Climate change scenarios, version 2.0. Community Climate System Model, June 2004 version 3.0. NCAR/UCAR. URL:http://www. gisclimatechange.org http://www.cesm.ucaredu/models/ccsm3.0/was used to derive data products (Accessed 01.06.14)

Norbury, G. L., Norbury, D. C., \& Heyward, R. P. (1998). Space use and denning behaviour of wild ferrets (Mustela fero) and cats (Felis catus). New Zealand Journal of Ecology, 22, 149-159.

Phillips, S., Anderson, R., \& Schapire, R. (2006). Maximum entropy modeling of species geographic distributions. Ecological Modelling, 190(3-4), 231-259. http://dx.doi.org/10.1016/j.ecolmodel.2005.03.026.

Phillips, S., \& Dudik, M. (2008). Modeling of species distribution with Maxent: new extensions and a comprehensive evaluation. Ecography, 31, 161-175.

Phillips, S. J., Dudík, M., Elith, J., Graham, C. H., Lehmann, A., Leathwick, J., et al (2009). Sample selection bias and presence-only distribution models: implications for background and pseudoabsence data. Ecological Applications, 19, 181-197.

Raxworthy, C. J., Martinez-Meyer, E., Horning, N., Nussbaum, R. A., Schneider, G. E., \& Ortega-Huerta, M. A. (2003). Predicting distributions of known and unknown reptile species in Madagascar. Nature, 426(6968), 837-841.

Radosavljevic, A. \& Anderson, R. P. (2014). Making better MAXENT models of species distributions: complexity, overfitting and evaluation. Journal of Biogeography, 41, 629-643.

Recio, M. R., Mathieu, R., Maloney, R., \& Seddon, P. J. (2010). First results of feral cats (Felis catus) monitored with GPS collars in New Zealand. New Zealand Journal of Ecology, 34(3), 288-296.

Schmidt, P. M., Lopez, R. R., \& Collier, B. A. (2007). Survival, fecundity, and movements of free-roaming cats. Journal of Wildlife Management, 71(3), 915-919. http://dx.doi.org/10.2193/2006-066.

Sherrouse, B. C., Semmens, D. J., \& Clement, J. M. (2014). An application of social values for ecosystem services (SolVES) to three national forests in Colorado and Wyoming. Ecological Indicators, 36, 68-79. http://dx.doi.org/10.1016/ j.ecolind.2013.07.008.

Shochat, E., Lerman, S. B., Anderies, J. M., Warren, P. S., Faeth, S. H., \& Nilon, C. H. (2010). Invasion, competition, and biodiversity loss in urban ecosystems. BioScience, 60(3), 199e208.

Simking, P., Wongnakphet, S., Stich, R. W., \& Jittapalapong, S. (2010). Detection of Babesia vogeli in stray cats of metropolitan Bangkok, Thailand. Veterinary Parasitology, 173(1e2), 70e75.

Sparkes, A. H., Bessant, C., Cope, K., Ellis, S. L. H., Finka, L., Halls, V., et al. (2013). ISFM guidelines on population management and welfare of unowned domestic cats (Felis catus). Journal of Feline Medicine and Surgery, 15(9), 811-817. http:// dx.doi.org/10.1177/1098612X13500431.

Swets, J. A. (1988). Measuring the accuracy of diagnostic systems. Science, 240, 1285-1293.

Syfert, M. M., Smith, M. J., \& Coomes, D. a (2013). The effects of sampling bias and model complexity on the predictive performance of MaxEnt species distribution models. PloS One, 8(2), e55158. http://dx.doi.org/10.1371/ journal.pone.0055158.

Thomas, R. L., Fellowes, M. D. E., \& Baker, P. J. (2012). Spatio-temporal variation in predation by urban domestic cats (Felis catus) and the acceptability of possible management actions in the UK. PLoS ONE, 7(11), e49369. http://dx.doi.org/ 10.1371/journal.pone.0049369.

Thomas, C. D., Franco, A. M. A., \& Hill, J. K. (2006). Range retractions and extinction in the face of climate warming. Trends in Ecology \& Evolution, 21(8), 415-416. 
http://dx.doi.org/10.1016/j.tree.2006.05.012.

Thuiller, W., Richardson, D. M., Pyšek, P., Midgley, G. F., Hughes, G. O., \& Rouget, M. (2005). Niche-based modelling as a tool for predicting the risk of alien plant invasions at a global scale. Global Change Biology, 11(12), 2234-2250.

Van Heezik, Y., Smyth, A., Adams, A., \& Gordon, J. (2010). Do domestic cats impose an unsustainable harvest on urban bird populations? Biological Conservation, 143(1), 121-130. http://dx.doi.org/10.1016/j.biocon.2009.09.013.

Veloz, S. D. (2009). Spatially autocorrelated sampling falsely inflates measures of accuracy for presence-only niche models. Journal of Biogeography, 36, 2290-2299. http://dx.doi.org/10.1111/j.1365-2699.2009.02174.x.

Wakie, T. T., Evangelista, P. H., Jarnevich, C. S., \& Laituri, M. (2014). Mapping current and potential distribution of non-native Prosopis juliflora in the afar region of
Ethiopia. PLoS ONE, 9(11), e112854. http://dx.doi.org/10.1371/ journal.pone.0112854.

Wasowicz, P., Pasierbinski, A., Przedpelska-Wasowicz, E. M., \& Kristinsson, H. (2014). Distribution patterns in the native vascular flora of Iceland. PLoS ONE, 9(7), e102916. http://dx.doi.org/10.1371/journal.pone.0102916.

Woods, M., McDonald, R., \& Harris, S. (2003). Predation of wildlife by domestic cats Felis catus in Great Britain. Mammal Review, 33(2), 174-188.

Yates, C. J., Elith, J., Latimer, A. M., Le Maitre, D., Midgley, G. F., Schurr, F. M., et al. (2009). Projecting climate change impacts on species distributions in megadiverse South African Cape and Southwest Australian Floristic Regions: opportunities and challenges. Austral Ecology, 35(4), 374-391. http://dx.doi.org/ 0.1111/j.1442-9993.2009.02044.x. 